\title{
OLIGONEMA FLAVIDUM (MYXOMYCETES): A SPECIES NEW TO POLAND
}

\author{
AGNIESZKA SALAMAGA
}

\begin{abstract}
This study presents the first collection of Oligonema flavidum (Peck) Peck in Poland. Its description, illustrations, substrate and habitat types are provided.
\end{abstract}

Key words: distribution, slime molds, Trichiaceae, central Poland

Agnieszka Salamaga, Institute of Botany, Jagiellonian University, Kopernika 27, 31-501 Kraków, Poland; e-mail: asalamaga@ wp.pl

\section{INTRODUCTION}

The genus Oligonema (Trichiaceae, Trichiales) was first specified and described by Rostafiński (1875). At present, seven species belong to the genus (Lado 2005-2013). Only one, Oligonema schweinitzii (Berk) G. W. Martin, has been found in Poland to date (Drozdowicz et al. 2003).

Oligonema flavidum (Peck) Peck was collected in central Poland in the Las Łagiewnicki Forest Reserve (Fig. 1). The taxon is new to the myxo-

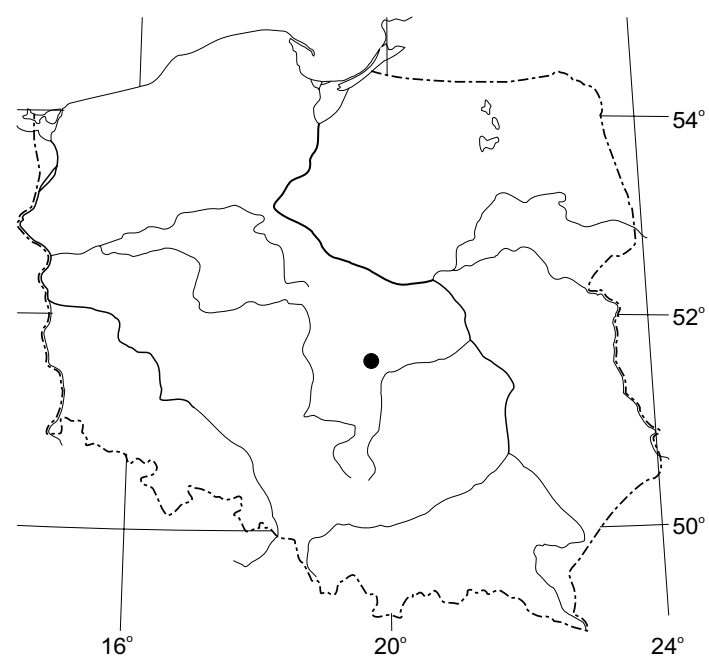

Fig. 1. Distribution map of Oligonema flavidum (Peck) Peck in Poland. mycete biota of Poland. This paper describes its morphological features together with photographic documentation and notes on its ecology and distribution.

\section{MATERIALS AND METHODS}

The study was based on material collected in the Las Lagiewnicki Forest Reserve during research on the myxomycete biota in this area. Morphological features were described from dry material. Permanent slides were made using Hoyer's medium. The material was observed with a Nikon YS100 light microscope and a Nikon SMZ-10A stereomicroscope. Spores were measured at $100 \times$ magnification with an oil immersion objective. The capillitium was measured at $40 \times$ magnification. Photographic documentation of the species was prepared with a Sony DSC H7 digital camera. The collection is deposited in the Herbarium of the Institute of Botany, Jagiellonian University (KRA), in the MYXO section.

\section{RESULTS}

Oligonema flavidum (Peck) Peck

Fig. 2

Sporocarps yellow, sessile, tightly crowded in heaps $2.5 \mathrm{~cm}$ long, the upper layer consisting of longitudinally elongated (height up to $1.5 \mathrm{~mm}$, width $0.4-0.5 \mathrm{~mm}$ ) or globose (height $0.5 \mathrm{~mm}$, width $0.3-0.4 \mathrm{~mm}$ ) sporocarps, the lower layer 

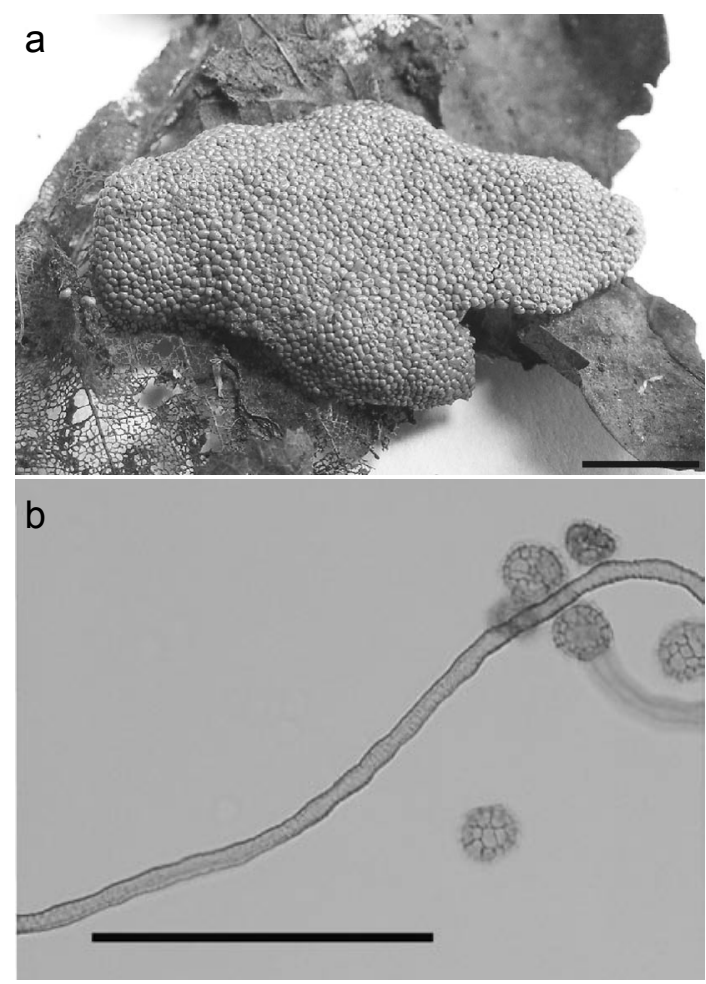

Fig. 2. Oligonema flavidum (Peck) Peck collected from the Las Łagiewnicki Forest Reserve. a - sporocarps, b - capillitium and spores. Scale bars: $\mathrm{a}-10 \mathrm{~mm}$ : $\mathrm{b}-100 \mu \mathrm{m}$.

built up of sporocarps irregular in shape. Peridium yellow, thin, covered with small warts. Capillitium of scant elaters, sporadically branched, covered with warts, in some parts narrowed or widened, 3-4 $\mu \mathrm{m}$ in diameter, 50-120 $\mu \mathrm{m}$ in length, ending with blunt apex. Spores yellow in mass, 14-15 $\mu \mathrm{m}$ in diameter, covered with almost complete coarsemeshed reticulum, 1-2 $\mu \mathrm{m}$ high.

MATERIAL EXAMINED: POLAND. ŁÓDŹ, LAS ŁAGIEWNICKI Reserve (51 $\left.49^{\prime} 55^{\prime \prime} \mathrm{N}, 19^{\circ} 28^{\prime} 34^{\prime \prime} \mathrm{E}\right)$, from dead litter of oak, hornbeam, birch and alder leaves. Specimen collected from a periodically inundated forest pond. 23 Aug. 2011, leg. A. Salamaga (KRA MYXO-9006).

REMARKS. Macro- and microscopic traits of this specimen are characteristic of the species, and parameters such as the size of sporocarps, spores and capillitum threads are within the ranges reported by other authors (Nannenga-Bremekamp 1991; Ing
1999; De Haan et al. 2004). The capillitum, which is scant in the specimen, is covered only with warts along its entire length while in other collections the warts can form thickened bands, in places resembling rings or spirals (Nannenga-Bremekamp 1991; de Haan et al. 2004; Ing 1999).

GENERAL DisTRIBUTION. Oligonema flavidum has been recorded from a number of European countries including Belgium, Estonia, Ukraine, Germany, Holland, Hungary and Russia (Lavits'ka 1949; Senge 1975; Nannenga-Bremekamp 1991; Adamonyte 2000; Revay \& Nagy 2005 Novozhilov et al. 2006; Dudka \& Krivomaz 2008 ) and from various parts of the world including the United States, Argentina, Algeria and India (Martin \& Alexopoulos 1969; Dhillon 1979; Ndiritu et al. 2009; Wrigley de Basanta et al. 2010; Ranade et al. 2012).

ECOLOGY AND HABITAT. The species does not seem to have specific substrate preferences. It was found on dead litter of oak, hornbeam, birch and alder leaves in the study area. It is recorded most often on dead wood of deciduous trees (Lavits'ka 1949; Senge 1975; Nannenga-Bremekamp 1991; Novozhilov et al. 2006; Wrigley de Basanta et al. 2010) and has also been found on mossy stumps (Novozhilov et al. 2006) and on rotten wood and moist soil (Poulain et al. 2011).

All species of the genus Oligonema prefer mesic habitats: wood and mosses in dry parts of ponds and streams (Ing 1999; de Haan et al. 2004). Oligonema flavidum was recorded in such a habitat in the Las Lagiewnicki Reserve.

ACKNOWLedgments. I thank Dr. Anna Drozdowicz (Kraków) and the anonymous reviewer for valuable comments on the manuscript, Tatiana Krivomaz (Kiev) for helping to compile literature, and David W. Mitchell (Sussex) and Dr. Joanna Kazik (Łódź) for reviewing the English.

\section{REFERENCES}

AdAmONYTE G. 2000. New data on Estonian myxomycete biota. Folia Cryptogamica Estonica 36: 7-9.

De HaAn M., De Pauw S. \& Bogaerts A. 2004. A study of the genus Oligonema (Myxomycota) in Belgium. Syst. Geogr. Pl. 74: 251-260. 
DHILLON S.S. 1979. Myxomycetes of North-Western Himalayas. Sydowia 32: 81-85.

Drozdowicz A., Ronikier A., Stojanowska W. \& PANeK E. 2003. Myxomycetes of Poland. A checklist. W. Szafer Institute of Botany, Polish Academy of Sciences, Kraków.

DUdKA I. O. \& KRIVOMAZ T. I. 2008. Myxomycetes of Ichnyansky National Nature Park of Ukraine. Mikol. Fitopatol. 42(5): 432-439 (in Russian with English summary).

ING B. 1999. The Myxomycetes of Britain and Ireland. An identification handbook. The Richmond Publishing Co. Ltd., Slough.

LADO C. 2005-2013. An on line nomenclatural information system of Eumycetozoa. [August 2013]. http://www.nomen. eumycetozoa.com.

LAVITS'KA Z. G. 1949. A contribution to the flora of slime moulds (Myxomycetes) of the Middle Dniper region. Works of Kaniv Biogeographical Research 7: 47-49 (in Ukrainian with English summary).

Martin G. W. \& Alexopoulos C. J. 1969. The Myxomycetes. Iowa City. University of Iowa Press.

NANNENGA-BREMEKAMP N. E. 1991. A guide to temperate Myxomycetes. Biopress Ltd., Bristol.

NDiritu G. G., Winsett K., SPiegel F. W. \& Stephenson S. L. 2009. A checklist of African Myxomycetes. Mycotaxon 107: 353-356.
Novozhilov Y. K., ZemLiansKaya V. I. \& SChNitTler M. 2006. Myxomycete diversity and ecology in the arid regions of the lower Volga River Basin (Russia). Fungal Diversity 23: 193-241.

Poulain M., Meyer M. \& Bozonnet J. 2011. Les Myxomycetes. Guide de détermination. Fédération Mycologique et Botanique Dauphiné-Savoie, Sévrier.

Ranade V. D., Korade S. T., Jagtap A. V. \& RanadiVe K. R. 2012. Checklist of Myxomycetes from India. Mycosphere 3(3): 358-390.

ReVAY A. \& NAGY L. 2005. Myxomycetes data from the Danube-Tisza interfluve and some other parts in Hungary. Stud. Bot. Hung. 36: 117-121.

RosTAFIŃSKI J. 1875. Śluzowce (Mycetozoa). Pamiętnik Towarzystwa Nauk Ścistych w Paryżu 6: 216-432.

SENGE W. 1975. Die bisher bekannten Myxomyceten Brandenburgs. Gleditschia 3: 53-83.

Wrigley de Basanta D., Lado C., Estrada-Torres A. \& STEPHENSON S. L. 2010. Biodiversity of myxomyctes in subantarctic forests of Patagonia and Tierra del Fuego, Argentina. Nova Hedwigia 90: 45-79. 